\title{
IDENTIFICATION OF POTENTIAL GROUNDWATER FLOW PATHS USING GEOLOGICAL AND GEOPHYSICAL DATA
}

\author{
Prepared by \\ Karl Pohlmann and Roko Andricevic
}

Submitted to

Nevada Operations Office

U.S. Department of Energy

September 1994

Publication \#45128 


\section{DISCLAIMER}

This report was prepared as an account of work sponsored by an agency of the United States Government. Neither the United States Government nor any agency thereof, nor any of their employees, make any warranty, express or implied, or assumes any legal liability or responsibility for the accuracy, completeness, or usefulness of any information, apparatus, product, or process disclosed, or represents that its use would not infringe privately owned rights. Reference herein to any specific commercial product, process, or service by trade name, trademark, manufacturer, or otherwise does not necessarily constitute or imply its endorsement, recommendation, or favoring by the United States Government or any agency thereof. The views and opinions of authors expressed herein do not necessarily state or reflect those of the United States Government or any agency thereof. 


\section{DISCLAIMER}

Portions of this document may be illegible in electronic image products. Images are produced from the best available original document. 
This report was prepared as an account of work sponsored by the United States Government. Neither the United States nor the United States Department of Energy, nor any of their employees, makes any warranty, express or implied, or assumes any legal liability or responsibility for the accuracy, completeness or usefulness of any information, apparatus, product or process disclosed, or represents that its use would not infringe privately owned rights. Reference herein to any specific commercial product, process, or service by trade name, mark, manufacturer, or otherwise, does not necessarily constitute or imply its endorsement, recommendation, or favoring by the United States Government or any ageney thereof. The views and opinions of authors expressed herein do not necessarily state or reflect those of the United States Government or any agency thereof.

This report has been reproduced directly from the best available copy.

Available to DOE and DOE contractors from the Office of Scientific and Technical Information, P.O. Box 62, Oak Ridge, TN 37831; prices available from (615) 576-8401.

Available to the public from the National Technical Information Service, U.S. Department of Commerce, 5285 Port Royal Rd., Springfield, VA 22161. 


\title{
IDENTIFICATION OF POTENTIAL GROUNDWATER FLOW PATHS USING GEOLOGICAL AND GEOPHYSICAL DATA
}

\author{
by \\ Karl Pohlmann and Roko Andricevic \\ Water Resources Center \\ Desert Research Institute \\ University and Community College System of Nevada
}

Publication No. 45128

prepared for

Nevada Operations Office

U.S. Department of Energy

Las Vegas, Nevada

September 1994

The work upon which this report is based was supported by the U.S. Department of Energy under Contract \#DE-AC08-90NV10845. 


\section{CONTENTS}

ABSTRACT $\ldots \ldots \ldots \ldots \ldots \ldots \ldots \ldots \ldots \ldots \ldots \ldots \ldots \ldots \ldots \ldots \ldots \ldots \ldots \ldots$

METHODOLOGY $\ldots \ldots \ldots \ldots \ldots \ldots \ldots \ldots \ldots \ldots \ldots \ldots \ldots \ldots \ldots \ldots \ldots \ldots$

SITE DESCRIPTION $\ldots \ldots \ldots \ldots \ldots \ldots \ldots \ldots \ldots \ldots \ldots \ldots \ldots \ldots \ldots \ldots$

PROBLEM FORMULATION $\ldots \ldots \ldots \ldots \ldots \ldots \ldots \ldots \ldots \ldots \ldots \ldots \ldots \ldots$

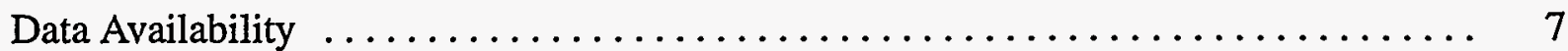

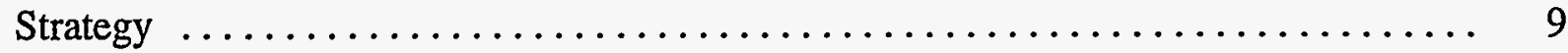

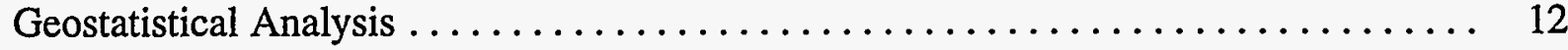

RESULTS AND DISCUSSION $\ldots \ldots \ldots \ldots \ldots \ldots \ldots \ldots \ldots \ldots \ldots \ldots \ldots \ldots \ldots \ldots$

CONCLUSIONS AND RECOMMENDATIONS $\ldots \ldots \ldots \ldots \ldots \ldots \ldots \ldots \ldots \ldots \ldots$

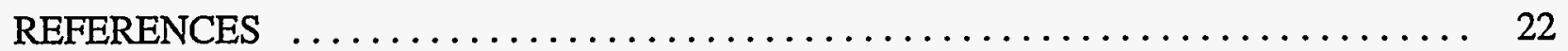




\section{FIGURES}

1. Location of study area and plan view of well locations in the SIS domain. ...... 5

2. North-south hydrogeologic cross section at $x=207,000 \mathrm{~m} \ldots \ldots \ldots \ldots \ldots$

3. Flow diagram showing the strategy developed to create three-dimensional maps of

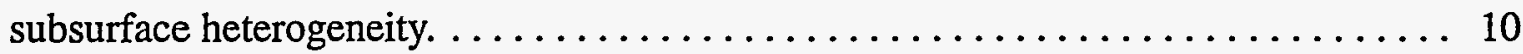

4. Resistivity log of well 24 showing resistivity threshold value and relationship to abridged geologic and hydrogeologic units.

5. Plots of (a) vertical semivariogram of known indicator data set, and (b) horizontal omnidirectional semivariogram of known indicator dataset. . . . . . . . . . . 13

6. Three-dimensional perspective of the subsurface map of the volcanic section. . . . 16

7. Comparison of (a) hydrogeologic cross section, (b) known indicator data from nearby wells projected on section, and (c) cross section through simulated subsurface map. .................................... 17

8. North-south cross sections through the simulated subsurface map at (a) $x=205,500 \mathrm{~m}$,

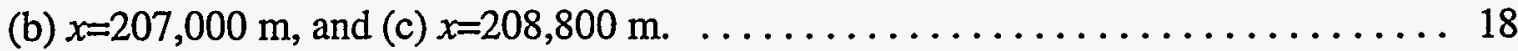

9. Horizontal cross section through the simulated subsurface map at $z=800 \mathrm{~m} . \ldots \ldots 19$

10. Comparison of three realizations of the subsurface map at 207,000 m east. . . . . 21

\section{TABLES}

1. Wells Used in this Study. $\ldots \ldots \ldots \ldots \ldots \ldots \ldots \ldots \ldots \ldots \ldots \ldots \ldots \ldots \ldots \ldots \ldots \ldots \ldots$

2. Ranges in Values of Bulk Density and Resistivity Associated with Various Rock Types at Yucca Flat $\ldots \ldots \ldots \ldots \ldots \ldots \ldots \ldots \ldots \ldots \ldots \ldots \ldots \ldots \ldots \ldots \ldots \ldots \ldots \ldots$ 


\begin{abstract}
This project represents the first phase in the development of a methodology for generating three-dimensional equiprobable maps of hydraulic conductivity for the Nevada Test Site (NTS). In this study, potential groundwater flow paths were investigated for subsurface tuffs at Yucca Flat by studying how these units are connected. The virtual absence of site-specific hydraulic conductivity data dictates that as a first step a surrogate attribute (geophysical logs) be utilized. In this first phase, the connectivity patterns of densely welded ash-flow tuffs were studied because these tuffs are the most likely to form zones of high hydraulic conductivity. Densely welded tuffs were identified based on the response shown on resistivity logs and this information was transformed into binary indicator values. The spatial correlation of the indicator data was estimated through geostatistical methods. Equiprobable three-dimensional maps of the distribution of the densely-welded and nonwelded tuffs (i.e., subsurface heterogeneity) were then produced using a multiple indicator simulation formalism.

The simulations demonstrate that resistivity logs are effective as soft data for indicating densely welded tuffs. The simulated welded tuffs reproduce the stratigraphic relationships of the welded tuffs observed in hydrogeologic cross sections, while incorporating the heterogeneity and anisotropy that is expected in this subsurface setting. Three-dimensional connectivity of the densely welded tuffs suggests potential groundwater flow paths with lengths easily over $1 \mathrm{~km}$. The next phase of this investigation should incorporate other geophysical logs (e.g., gamma-gamma logs) and then calibrate the resulting soft data maps with available hard hydraulic conductivity data. The soft data maps can then augment the hard data to produce the final maps of the spatial distribution of hydraulic conductivity that can be used as input for numerical solution of groundwater flow and transport.
\end{abstract}




\section{INTRODUCTION}

When the focus of groundwater problems shifted from water supply to contaminant migration and resulting risk assessments, more sophisticated description of the subsurface became necessary. The geologic heterogeneity in natural formations (e.g., hydraulic conductivity, $K$; porosity; storage coefficient) is manifested by a complex spatial variability while the available information on this spatial variability is limited. As a result, it is virtually impossible to construct a detailed deterministic description of such natural heterogeneity. Determination of the continuity of high hydraulic conductivity zones within an area of study is crucial in predicting contaminant migration and assessing the potential risk that may result from that migration. In a heterogeneous formation with hydraulic conductivity values differing by several orders of magnitude (e.g., fractured rock), flow occurs primarily through connected paths of high conductivity. Randomly disconnected small fractures may not generate flow paths, whereas a very small volume proportion of connected high conductivity zones may control the migration and thus may become a major contributor to the potential risk.

In the last decade, a stochastic framework for describing subsurface heterogeneity has emerged (Delhomme, 1979; Dagan, 1986; Gelhar, 1986) and has become the only way to mathematically account for this natural geologic heterogeneity. The most common approach, that is widely accepted today, is to generate a set of equiprobable subsurface geologic maps conditioned on the available hard data. Then, simulating the contaminant migration for each subsurface map, the resulting set of responses (e.g., contaminant plumes) is obtained as a distribution of equiprobable outcomes. This type of subsurface generation of heterogeneity is based on the so-called single covariance description, which means that the subsurface attribute (e.g., hydraulic conductivity) is generated based on a single spatial correlation structure inferred from the available data set (e.g., using geostatistical techniques). However, a single covariance measure does not distinguish among low, medium, and high conductivity values. It is, therefore, important to have the ability to generate subsurface maps with the connectivity description of those highly conductive flow paths.

In practice, the available field data can be divided into two categories:

1. Hard data: This is the actual measured attribute (e.g., hydraulic conductivity, porosity, etc.) at a specific location with a low degree of uncertainty. Unfortunately, this type of data is usually sparse.

2. Soft data: This type of data is qualitative or quantitative in nature and has various degrees of uncertainty associated with it. These data include but are not limited to: geologic information (e.g., rock type, core log, tectonic structure analysis), geophysical information (e.g., well logging, seismic data), or simply expert judgment. Usually this type of data is available.

It is the intention of this study to demonstrate a procedure for generating equiprobable maps of subsurface heterogeneity using all available data while particularly focusing on detecting the connectivity patterns of high hydraulic conductivity zones. We follow the indicator formalism (Journel, 1989; Journel and Alabert, 1989) which allows the interpretive information to be 
commonly coded into elementary bits (valued at zero or one). These bits are then processed independently of their origins (hard or soft data) to generate subsurface maps of the studied area. We start this project using the Yucca Flat region at the Nevada Test Site (NTS) as a case study to demonstrate the three-dimensional subsurface heterogeneity and potential connectivity patterns of highly conductive regions.

\section{METHODOLOGY}

This study uses the sequential indicator conditional simulation (SIS) algorithm to generate equiprobable maps of subsurface heterogeneity. As described by Alabert (1987), the SIS algorithm estimates a value of the subsurface attribute at an unsampled location such that the new value is consistent with the inferred spatial correlation structure of that variable. The newly simulated value is then added to the existing data set (conditioning data) and the process is repeated. The original conditioning data include only the known data, but as the SIS simulation proceeds, the conditioning data set grows with the addition of each newly simulated data point. Therefore, the final simulated map honors the known data at their locations as well as the spatial correlation structure inferred from the known data set.

Using SIS, the values of the input data and simulated field are not continuous, but are assigned to classes which divide the total range of variability of the subsurface attribute. The classes are separated by threshold values that are chosen to divide the range of variability into meaningful classes. For example, hydraulic conductivity might be divided into three classes such as low, medium, and high $K$. In this case, the lower threshold value might be chosen such that the values of $K$ in the lowest class might result in minimal flow. Likewise, the upper threshold might be chosen such that values of $K$ in the highest class might result in significant groundwater flow velocities. The probability that a variable is in a particular class is determined by its indicator value. Indicators are a transform of the data values and represent the expected probability that the value of a variable at a particular location is less than or equal to the threshold value. The indicator has a value of one if the value of the variable is less than or equal to the threshold, and a value of zero if the value of the variable is greater than the threshold.

Namely, instead of working with actual values of the attribute $Z(x)$, as in classical geostatistics, a nonparametric approach considers the indicator values $I\left(x ; z_{c}\right)$ defined as

$$
I\left(x ; z_{c}\right)=1 \text { if } Z(x) \leq z_{c} ; I\left(x ; z_{c}\right)=0 \text { if } Z(x)>z_{c}
$$

where $z_{c}$ is a selected threshold. This indicator formalism allows any available data (hard or soft) to be coded into binary bits. The average value of $I\left(x ; z_{c}\right)$ over the entire domain represents the cumulative probability distribution of $Z(x)$ at $z_{c}$; that is, the proportion of $Z(x)$ that is below the value $z_{c}$, i.e., $E\left\{I\left(x ; z_{c}\right)\right\}=P\left\{Z(x) \leq z_{c}\right\}=p_{z c}$. 
The expected value of the product $I\left(x ; z_{c}\right)$ and $I\left(x^{\prime} ; z_{c}\right)$ is the noncentered covariance and represents the bivariate distribution of $Z(x)$ for locations $x$ and $x^{\prime}$ for threshold $z_{c}$ :

$$
E\left\{I\left(x ; z_{c}\right) I\left(x^{\prime} ; z_{c}\right)\right\}=P\left\{Z(x) \leq z_{c} ; Z\left(x^{\prime}\right) \leq z_{c}\right\}
$$

The above equation is a measure of two-point spatial continuity. The higher the covariance, the greater the probability of having two values $Z(x)$ and $Z\left(x^{\prime}\right)$ which jointly do not exceed the same threshold value $z_{c}$ (Journel and Alabert, 1989). Thus, this indicator covariance accounts for the spatial connectivity pattern at different selected thresholds. When this connectivity pattern indicates layers and lenses of high hydraulic conductivity, the potential groundwater flow paths can be identified. The importance of such connected flowpaths is in the fact that although they may transport only a small volume of water, the solute concentrations in this water may be very high.

The procedure for generating equiprobable maps of subsurface heterogeneity using the SIS algorithm begins by establishing the size and orientation of the problem domain. If the hydrogeologic units are assumed to be flat and of uniform thickness, a Cartesian coordinate system can be used with the horizontal coordinate axes being the map horizontal easting and northing. In this case, the horizontal variogram models are oriented in Cartesian coordinates, without regard to the actual stratification or orientation of the units in space. Alternatively, if hydrogeologic units are not flat lying and/or they exhibit variable thickness, then a coordinate system that conforms to the stratigraphy of the unit can be used. This stratigraphic coordinate system can then be transformed into a rectangular grid for semivariogram modeling and SIS simulations. In this way, the "horizontal" variograms are oriented within individual units and the lateral continuity of each unit is preserved.

Once the problem domain has been established, the subsurface attribute is chosen and the classes and threshold values are established. Indicator values are then assigned to the known data and the spatial correlation structure of each threshold is estimated through geostatistical methods. Semivariograms of each threshold are computed in each of the coordinate directions of the problem domain to determine the sill, range, and semivariogram model to be used in the SIS simulations.

The simulations in this study were generated using the computer program ISIM3D, a three-dimensional, multiple indicator, conditional simulation program developed by Gomez-Hernandez and Srivastava (1990). ISIM3D allows the use of both hard and soft data in the simulations.

The simulation consists of the following steps (Gomez-Hernandez and Srivastava, 1990):

1. A random path is defined through all the nodes to be simulated. The simulation proceeds sequentially along this path with the operations described below implemented at each node to be simulated.

2. The conditioning data present within a given search neighborhood are identified and the closest data points are retained for kriging. 
3. For each indicator threshold, a kriging system using the indicator semivariogram model is set up and solved.

4. The kriging weights are used to compute the conditional probability distribution function (cpdf) using the indicator conditioning data for the current threshold. The cpdf provides the probability that the value of the attribute at the present node does not exceed the threshold value, in other words, the probability that the attribute is in the lower class.

5. A uniform random number between zero and one is drawn. If the number is less than or equal to the cpdf at the current node, the node is assigned to the lower class with an indicator of zero. Otherwise, the node is assigned to the higher class with an indicator of one.

6. The node just simulated is then included in the conditioning data set and the . simulation proceeds.

Once the value at every node has been simulated, the resultant matrix represents one realization of the subsurface heterogeneity. To obtain additional equiprobable realizations the simulation is repeated with a different random path through the nodes and a different random number seed.

\section{SITE DESCRIPTION}

A preliminary characterization of the hydrogeology in southern Yucca Flat was conducted to provide first-cut approximations of the distribution of hydrogeologic variables. Hydrogeologic conditions and data availability were used to define the problem domain and its orientation in space. An area covering parts of NTS Areas 1, 3, 4, and 7 in Yucca Flat was chosen (Figure 1). The area contains 24 wells that all had available lithologic and extensive geophysical logs (Table 1).

Yucca Flat is a typical Basin and Range graben containing up to $600 \mathrm{~m}$ of Quaternary alluvial valley fill derived from the surrounding mountain blocks. The alluvium is generally unsaturated in Yucca Flat. Underlying the alluvium is a thick sequence of Tertiary volcanic rocks consisting of air-fall, ash-flow, and reworked tuffs. Densely-welded ash-flow tuffs and vitrophyres within the upper portion of this section tend to be fractured, and when deep enough to be saturated, are considered aquifers (the "welded-tuff" aquifer of Winograd and Thordarson, 1975). Although the welding of these units reduces matrix porosity to very low values, it also causes them to be subject to fracturing. Connected fracture zones within densely-welded tuffs and/or vitrophyres may create pathways for groundwater flow.

Air-fall and ash-flow tuffs below the densely-welded ash-flow tuffs tend to be nonwelded or partially welded and are generally zeolitized. Although matrix porosity of these units may be high, most pores are unconnected so the effective porosity is low. In addition, the clay and zeolite matrices of these rocks tend to reduce the interstitial hydraulic conductivity to very low values. Finally, nonwelded tuffs contain few fractures so they are unlikely to act as important flow paths. Taken as a whole, these tuffs comprise the "tuff aquitard" that restricts movement of groundwater below Yucca Flat (Winograd and Thordarson, 1975). The tuff aquitard is bounded below by Paleozoic 


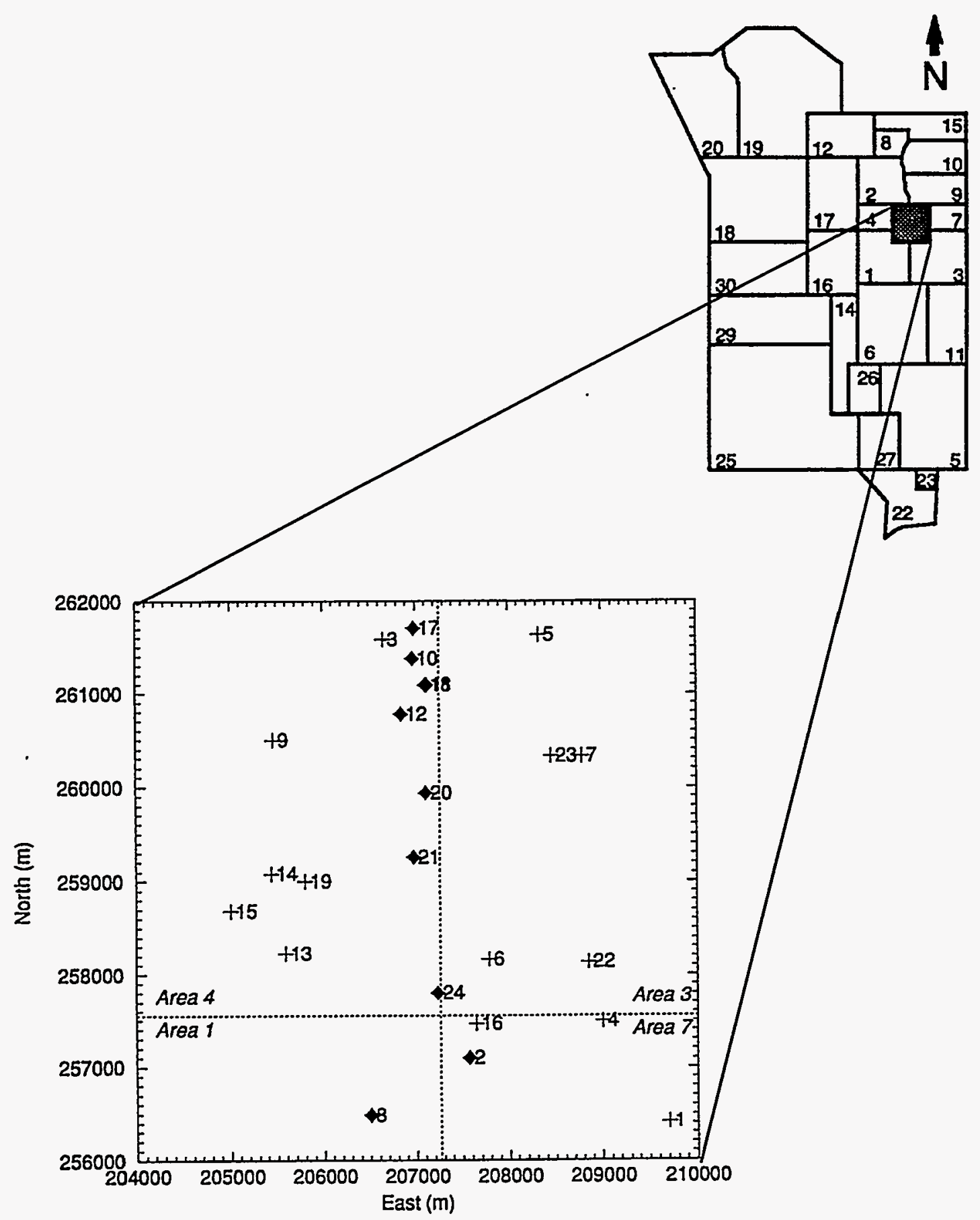

Figure 1. Location of study area and plan view of well locations in the SIS domain. Wells indicated by diamonds have been projected on a cross section at $x=207,000 \mathrm{~m}$. 
Table 1. Wells Used in this Study.

\begin{tabular}{llll}
\hline Well ID & NTS Well Name & Easting $(\mathrm{m})$ & Northing $(\mathrm{m})$ \\
\hline \hline 1 & U 3cn & 209702.2 & 256415.0 \\
2 & U 3gg & 207569.2 & 257099.0 \\
3 & U 4e & 206654.8 & 261580.2 \\
4 & U 7ai & 209001.5 & 257495.9 \\
5 & U 7ak & 208327.9 & 261634.7 \\
6 & U 7an & 207782.6 & 258166.1 \\
7 & U 7bs & 208788.4 & 260330.2 \\
8 & UE 1q & 206502.4 & 256489.7 \\
9 & UE 4av & 205459.1 & 260494.8 \\
10 & UE 4d1 & 206971.2 & 261376.0 \\
11 & UE 4g2 & 207126.9 & 261092.2 \\
12 & UE 4t & 206847.7 & 260776.7 \\
13 & UE 4ae & 205588.0 & 258227.1 \\
14 & UE 4ah & 205435.6 & 259080.5 \\
15 & UE 4al & 204999.7 & 258684.3 \\
16 & U 3la & 207640.8 & 257465.1 \\
17 & U 4a & 206989.8 & 261702.7 \\
18 & U 4g & 207111.7 & 261092.2 \\
19 & U 4i & 205801.4 & 259000.7 \\
20 & U 4j & 207111.7 & 259934.3 \\
21 & U 4r & 206976.4 & 259254.9 \\
22 & U 7ac & 208849.4 & 258135.6 \\
23 & U 7ah & 208453.7 & 260330.2 \\
24 & U 7aq & 207234.2 & 257800.3 \\
\hline
\end{tabular}

rocks that form an important aquifer/aquitard system that defines the regional flow of groundwater (Winograd and Thordarson, 1975). A simplified north-south hydrogeologic cross section through wells that were used in this study is presented in Figure 2.

The Cartesian coordinate system was used in this study to simplify the analysis and was considered appropriate because the tuff units are relatively flat lying and of relatively uniform thickness. The coordinate axes were defined as follows: $x$ is East, $y$ is North, and $z$ is elevation above mean sea level. Horizontal locations are given in Nevada State Coordinate System coordinates and expressed as meters $(\mathrm{m})$. 


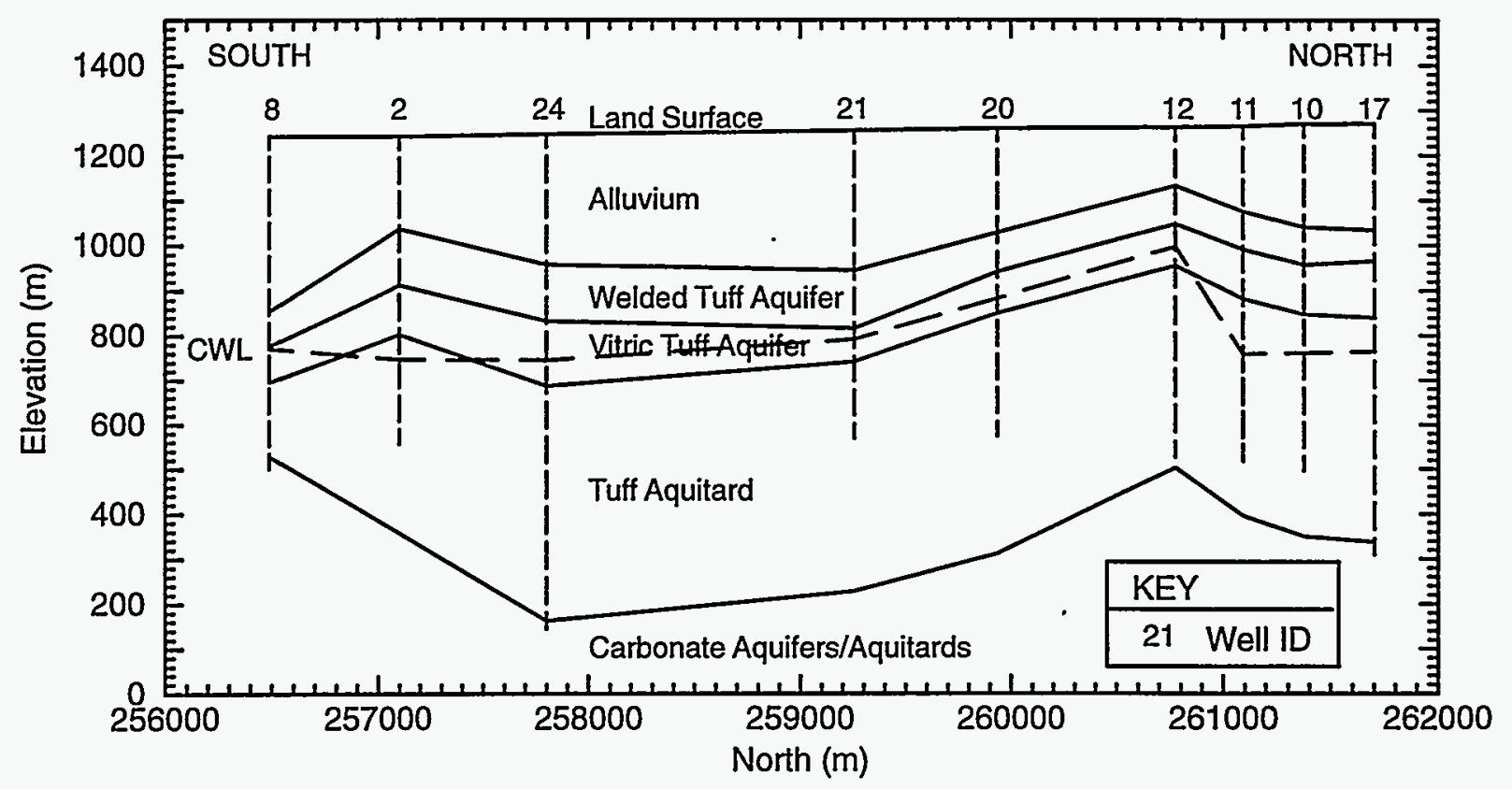

Figure 2. North-south hydrogeologic cross section at $x=207,000 \mathrm{~m}$ (data from Drellack and Thompson, 1990). Data from the wells shown are projected on the section, while the upper surface of the carbonates is derived from a contour map of the area. CWL is the composite water level measured in the boreholes.

\section{PROBLEM FORMULATION}

\section{Data Availability}

At the NTS there is an important need to identify potential flowpaths for groundwater movement so the variable of particular interest is hydraulic conductivity, $K$. Under ideal conditions, hard $K$ data can be supplemented by soft data to provide a more complete representation of the spatial distribution of potential flow paths. At some sites there may be some hard $K$ data and a roughly equal amount of soft data that can be used to supplement the hard data. At these sites, $K$ is chosen as the hydrogeologic attribute (as hard data) and the stochastic realizations of $K$ in space are produced directly.

However, the availability of hard $K$ data at most sites is very limited. As an alternative, some of these sites may have a great deal of soft data available. The choice of the type of soft data to be used as the subsurface attribute depends on the data availability and the relationship between the soft data "signal" and the hydrogeologic variable of interest. For example, some types of soft data, such as lithologic logs and geologic maps, may have low spatial resolution and little direct relation to hydraulic conductivity. On the other hand, certain geophysical logs may provide information on the nature of the hydrogeologic units and therefore may provide relatively direct information on hydrogeologic variables. For example, the signals produced by certain geophysical logs may be directly or indirectly related to formation porosity or hydraulic conductivity. If a relation can be 
established between a specific log signal and a particular hydrogeologic attribute, data from the logs can be used as hard data representing that particular attribute. The map produced in this way describes the spatial distribution of the hydrogeologic attribute while incorporating little or no hard data. By calibrating the soft data with hard data (e.g., measurements of $K$ ) at known locations, the soft data map can be used to increase the amount of hard data. The benefits of using this approach to study potential groundwater flow paths at the NTS are clear. In the case of Yucca Flat, very little hard $K$ data are available, but there is a very large amount of geophysical log data available.

Three geophysical logs that may be useful to the description of hydrogeologic variables in the volcanic units at Yucca Flat are the gamma-gamma ("density") log, neutron ("porosity") log, and the resistivity ("electric") log. The brief description of these logging methods presented here is based on Keys (1990) and Drellack (1994). The relation of the logs to NTS geology is based on the work of Drellack (1994). The gamma-gamma log uses a gamma radiation source to measure electron density in the formation. Electron density is approximately proportional to bulk density for most rocks and the higher the bulk density, the more the gamma signal is attenuated. The bulk density can be converted to an estimate of porosity if fluid and grain density are known, although effective porosity is difficult to distinguish from total porosity. The gamma-gamma signal in volcanic rocks on the NTS is primarily a function of porosity and welding, and to a lesser extent, mineral alteration. Porosities of ash-flow tuffs range up to 50 percent while porosities in a densely-welded vitrophyre may be as low as three percent. While porosity decreases as degree of welding increases, grain density increases with increasing degree of welding. Therefore, densely-welded ash-flow tuffs generally can be distinguished from non-welded tuffs by their higher gamma-gamma (density) signal. If densely-welded tuffs are significantly fractured, they may represent zones of high relative $K$, and therefore may be a potential pathways of groundwater flow.

The neutron logging tool emits neutrons and records their interactions with adjacent rocks. The number of these interactions is controlled by the quantity of hydrogen present, which is a function of the water content. In a fully saturated rock a low neutron count generally indicates high porosity, as a result of the high proportion of the rock volume occupied by water molecules. As with the gamma-gamma log, the neutron log cannot distinguish between total and effective porosity. At the NTS, volcanic rocks with higher density or lower porosity generally have lower water content and therefore usually exhibit high neutron signals. These conditions may indicate a fractured, denselywelded tuff that may be a potential pathway for groundwater flow. In contrast, volcanic rocks that have high porosity (air-fall and nonwelded ash-flow tuffs) and/or are altered by zeolitization usually exhibit low neutron signals (high apparent water content). These rocks generally are considered to have very low hydraulic conductivity.

The resistivity tool measures the resistance of a volume of rock to the flow of an electrical current. Most rocks are not good conductors of electricity so resistivity is a function of the resistance and volume of pore water. The resistivity $\log$ is a measure of effective porosity because the electric current can flow only through connected pores. The resistance of pore water in the tuffs at Yucca Flat is fairly uniform and is relatively high due to its low dissolved solids content. Therefore, the resistivity of tuffs at Yucca Flat is primarily a function of porosity. Air-fall and nonwelded ash-flow 
tuffs have high porosity and exhibit low resistivity. As the degree of welding increases, the porosity is reduced and the resistivity increases. Densely-welded tuffs and rhyolite lava flows have the highest resistivities. Zeolitization has the effect of lowering apparent resistivity in all tuffs because the pore water has lower resistance. As a result of these relationships, a high resistivity response is likely to indicate a potential pathway of groundwater flow, while a low response is likely to indicate a potential barrier to groundwater flow.

\section{Strategy}

The intention of this project is to establish the methodology to utilize as many available data as possible for generating equiprobable maps of hydraulic conductivity. The steps required to reach this objective are listed below and in the flow chart in Figure 3.

1. Evaluate the hydrostratigraphic units with the objective of identifying specific units with high potential for flow paths and their spatial connectivity. For this purpose we select the electrical resistivity logs to serve as hard data information.

a. Select the threshold for the resistivity logs such that the densely-welded and nonwelded tuff units can be differentiated. The proper coding based on indicator formalism in equation (1) is performed and a semivariogram analysis is conducted for each selected threshold.

b. Calculate the SIS algorithm and generate the three-dimensional volume data based on the selected threshold. The cross-sectional maps indicate the spatial anisotropy and connectivity patterns found.

2. Utilize the gamma-gamma logs to distinguish nonwelded tuffs from densely-welded tuffs. A procedure similar to that used for the electrical resistivity logs is performed and equiprobable maps are generated. Other logs may also be considered for inclusion in the analysis at this time.

3. Compare and calibrate available hard data the geophysical logs used in the preceding steps. If there are not enough hard data present at the selected site, neighboring sites with the same geological units can be used as surrogates (e.g., Yucca Mountain data).

4. In this step, the maps generated in the previous steps, which are based solely on geophysical data, become the soft information for maps of hydraulic conductivity.

a. Formulate the soft information of different types and code them into the indicator formalism and then use them to augment the available hard data.

b. Evaluate all indicator variograms for selected thresholds and execute the SIS algorithm. Generate equiprobable maps of hydraulic conductivity based on hard and soft data.

5. Generate for each identified class of hydraulic conductivity, based on the calibration between the hard and soft data, the spatial distribution of actual conductivity values. Superimpose the subsurface maps and identify the final maps.

6. Use the final maps of hydraulic conductivity as input for numerical models of groundwater flow and transport.

During the first year (FY 1994) of this proposed multi-year project, the first step has been completed and subsurface maps based on resistivity logs have been generated. 


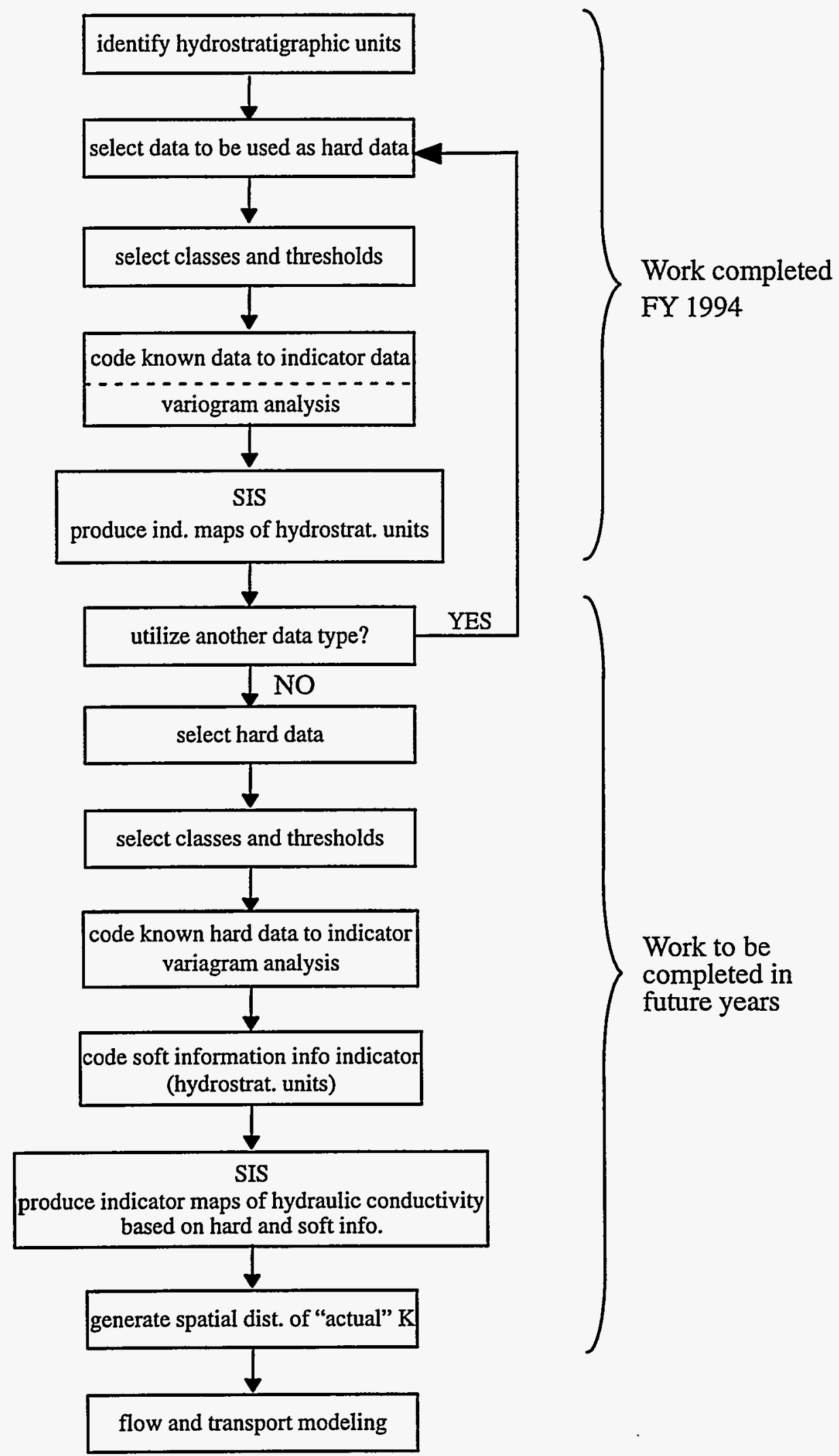

Figure 3. Flow diagram showing the strategy developed to create three-dimensional maps of subsurface heterogeneity. 
All three of the geophysical logs described above may be suitable for soft data simulation because they all can be used to differentiate between densely-welded tuffs and nonwelded tuffs. However, interpretation of the gamma-gamma and resistivity logs appears to be most straightforward. Numerical ranges for values of bulk density (derived from the gamma-gamma log) and resistivity typical of selected rock types on the NTS are shown in Table 2. Potential flow paths, if assumed to be represented by densely-welded tuffs and vitrophyres, exhibit an easily identifiable and distinct response on these logs. Air-flow tuffs, nonwelded ash-flow tuffs, and zeolitized tuffs, which are assumed to represent potential barriers, exhibit a distinctly different response in each log.

Resistivity logs were chosen for this phase of the study because of their availability and relative ease of interpretation. Blankennagel and Weir (1973) also used resistivity logs to differentiate permeable densely-welded tuffs and vitrophyres from relatively impermeable zeolitized tuffs. They used a threshold resistivity value of $225 \mathrm{ohms}-\mathrm{m}^{2} / \mathrm{m}$. We have chosen a threshold value of 300 $\mathrm{ohm}-\mathrm{m}^{2} / \mathrm{m}$ for this study in order to represent only the more densely-welded tuffs. Based on the relationships presented in Table 2, resistivity values above this threshold represent moderate- to densely-welded tuffs and therefore indicate zones that may act as groundwater flow paths, while resistivity values below this threshold suggest zones where groundwater flow is comparatively minimal.

Table 2. Ranges in Values of Bulk Density and Resistivity Associated With Various Rock Types at Yucca Flat (after Drellack, 1994). Note for both logs that the densely-welded ash-flow tuffs have the highest response within the volcanic rocks.

\begin{tabular}{|c|c|c|}
\hline \multirow[b]{2}{*}{ Rock Type } & \multicolumn{2}{|c|}{ Approximate Range } \\
\hline & $\begin{array}{l}\text { Bulk Density } \\
\text { (g/cc) }\end{array}$ & $\begin{array}{l}\text { Apparent Resistivity } \\
\text { (ohm- }-\mathrm{m}^{2} / \mathrm{m} \text { ) }\end{array}$ \\
\hline Alluvium & $1.60-1.80$ & $20-300$ \\
\hline \multicolumn{3}{|l|}{ Ash-Flow Tuffs } \\
\hline Nonwelded & $1.40-1.75$ & $110-750$ \\
\hline Partially to Moderately Welded & $1.75-2.20$ & $145-650$ \\
\hline Densely Welded $^{1}$ & $2.20-2.40$ & $700-1000$ \\
\hline Air-Fall Tuffs ${ }^{2}$ & $1.60-2.20$ & $20-100$ \\
\hline Paleozoic Rocks & $2.20-2.85$ & $40-200+$ \\
\hline
\end{tabular}


The value at each measured data point was transformed to an indicator class based on the class in which it falls; zero if below the threshold, one if above the threshold. Resistivity logs from 24 wells were utilized. To reduce the amount of redundant data for subsequent analysis, the continuous logs were sampled at an interval of approximately $1 \mathrm{~m}$. Each log then had an average of 508 resistivity measurements. An example of how the data in a typical resistivity log are transformed into the two classes is shown in Figure 4. Note that welded tuffs (the upper class) appear to represent only a portion of the welded-tuff aquifer.

\section{Geostatistical Analysis}

The spatial correlation structure of the known indicator data was analyzed through a geostatistical study of the entire 12,200-point known indicator data set. Semivariograms were calculated for the vertical and horizontal (omnidirectional) directions using the GSLIB geostatistical software library (Deutsch and Journel, 1992) and are presented in Figure 5. Spherical theoretical semivariogram models were selected to represent both experimental semivariograms. Note that ISIM3D requires that the sill and nugget have the same value in all coordinate directions. The values from the vertical semivariogram were chosen because the vertical data have much finer resolution (approximately $1 \mathrm{~m}$ ) than the horizontal data between wells. Note, however, that both semivariograms exhibit similar values for the nugget and sill. As might be expected by the data distribution and hydrogeologic setting, the horizontal range was much larger than the vertical, 650 $\mathrm{m}$ verses $160 \mathrm{~m}$.

\section{RESULTS AND DISCUSSION}

The domain shown in Figure 1 was discretized into a regular grid of 158,661 nodes with 51 nodes in each of the horizontal dimensions ( $x$ is East, $y$ is North), and 61 nodes in the vertical dimension ( $z$ is elevation). Node spacing was $120 \mathrm{~m}$ in the $x$ and $y$ dimensions and $10 \mathrm{~m}$ in the $z$ dimension. The grid covers the volume bounded by $x=204,000$ and $210,000 \mathrm{~m} ; y=256,000$ and $262,000 \mathrm{~m}$; and $z=400$ and $1000 \mathrm{~m}$. This study focused primarily on the volcanic section, however, portions of alluvium and Paleozoic rock were also included in the problem domain due to the variable depths of the units. Although groundwater flow is likely within these zones, the resistivity log may respond differently to them and therefore zones of apparent densely-welded tuffs may be generated in the nonvolcanic rocks, particularly if known conditioning data are absent. This effect was not prevented for this study, but could easily be addressed through the use of other soft geologic data.

Resistivity was used as the subsurface attribute to indicate the presence of welded tuff verses nonwelded tuff. As discussed above, welded tuffs may act as groundwater flow paths within the volcanic section at Yucca Flat. Two classes of resistivity were utilized with the threshold value set at $300 \mathrm{ohm}-\mathrm{m}^{2} / \mathrm{m}$. The nodes where the indicator value is simulated to be one (resistivity value above this threshold) represent areas of welded tuff. A significant potential flow path may exist if several of these welded-tuff nodes are connected. Likewise, the nodes where the indicator value is simulated to be zero (resistivity value below the threshold) represent areas of nonwelded tuff. 


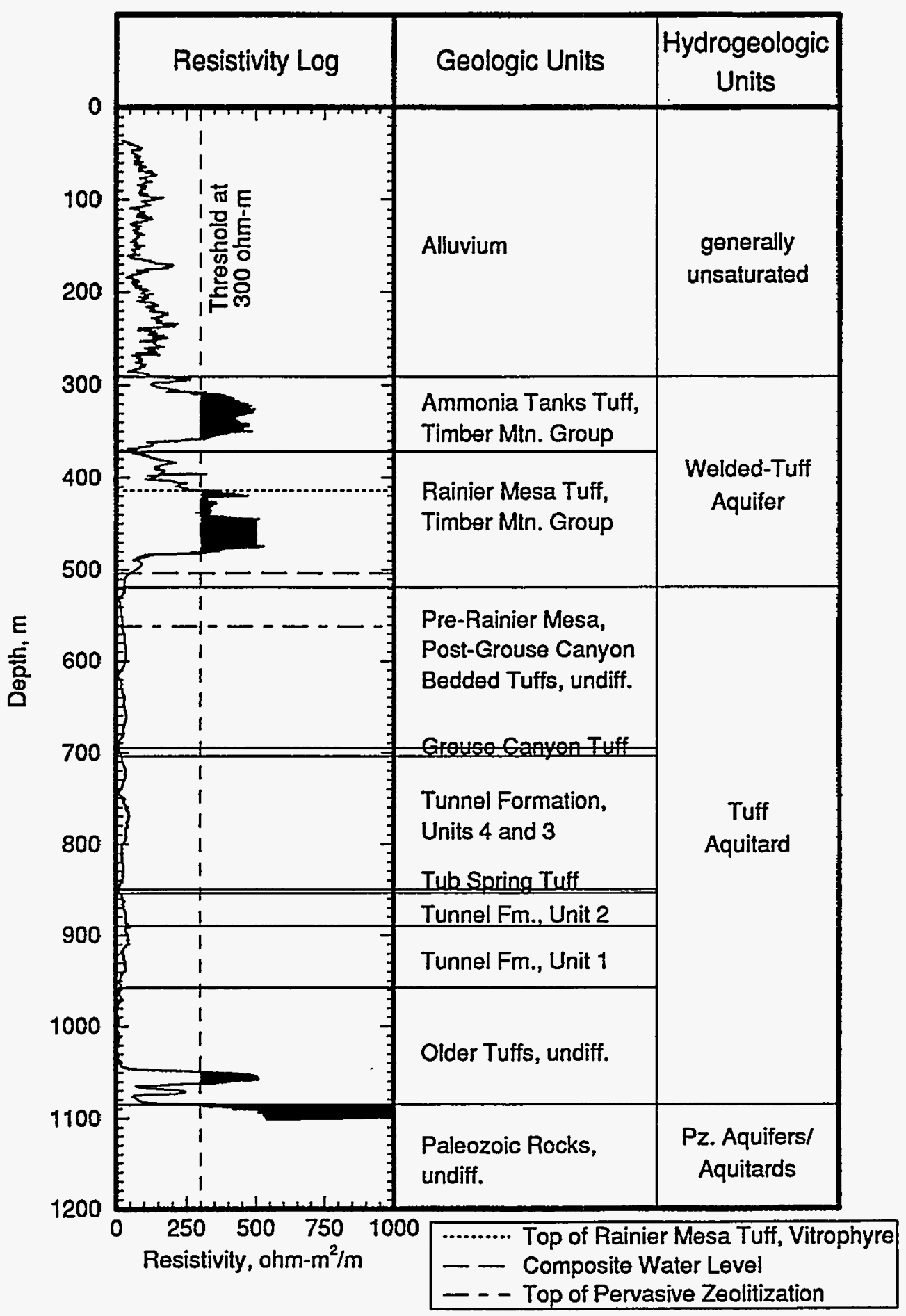

Figure 4. Resistivity log of well 24 showing the resistivity threshold value of $300 \mathrm{ohm}-\mathrm{m}^{2} / \mathrm{m}$ and relationship to abridged geologic and hydrogeologic units (geologic data from Drellack and Thompson, 1990). Shaded areas indicate where resistivity is above the threshold value. Note that the resistivity log suggests that only a portion of the welded tuff aquifer may be densely welded. 

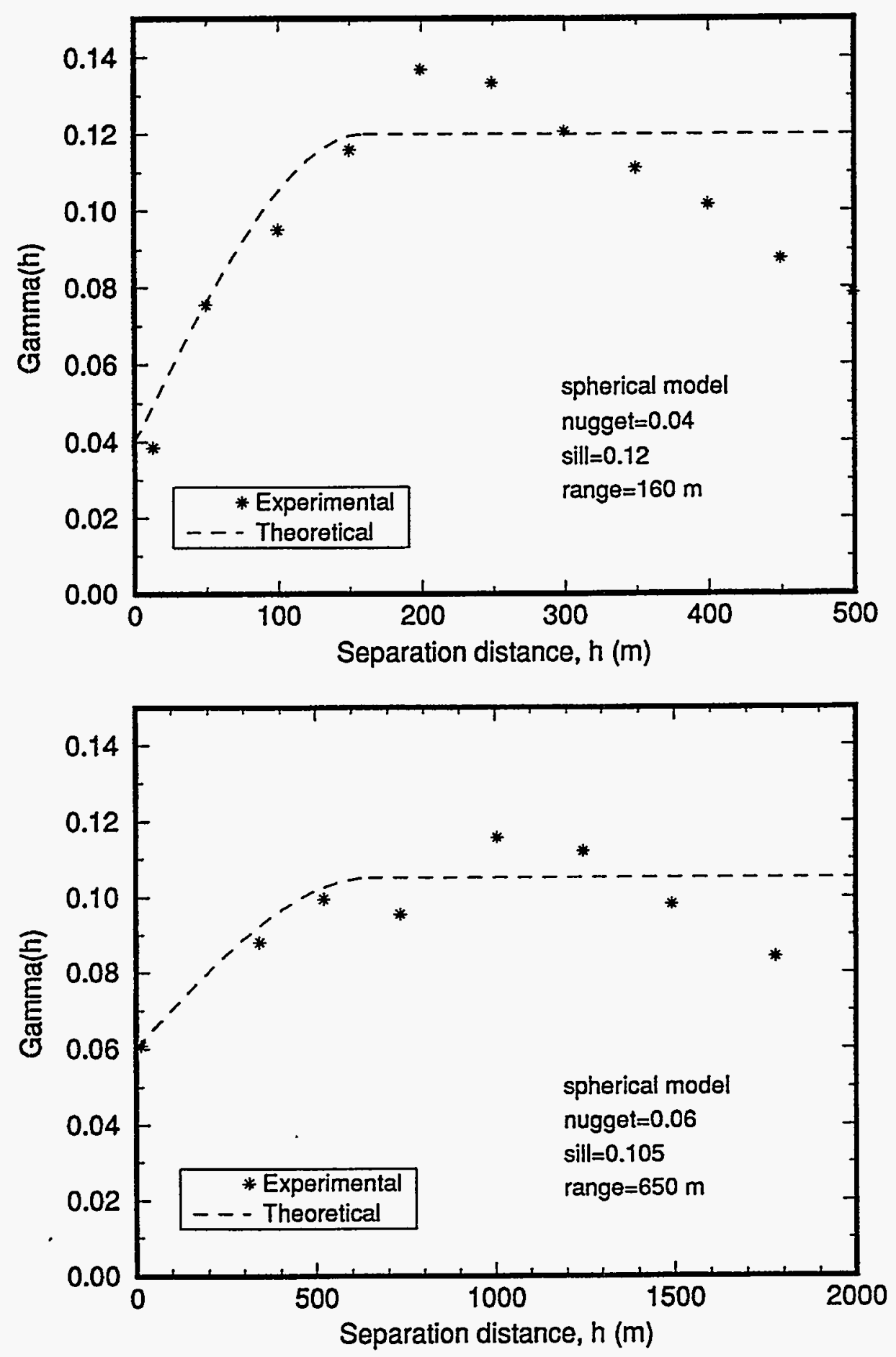

Figure 5. Plots of (a) vertical semivariogram of known indicator data set, and (b) horizontal omnidirectional semivariogram of known indicator dataset. 
Connected nodes of this type suggest a potential barrier to groundwater flow. During the simulations, the conditioning of the current location was conducted using the four nearest data points in each of eight octants of the search ellipsoid.

A three-dimensional perspective of one equiprobable realization of the subsurface map of welded and nonwelded tuffs is shown in Figure 6 where the dark areas indicate welded tuffs. The geologic heterogeneity that is expected within natural geologic formations is clearly evident in this map. Some degree of connectivity of the tuff units is apparent, although it should be pointed out that this figure represents the simulated conditions on the outer edges of the domain where known conditioning data are sparse. More useful information can be obtained by looking within this volume.

Figure 7a shows one equiprobable map of a vertical cross section at $x=270,000 \mathrm{~m}$ through the subsurface data shown in Figure 6. The black areas represent the high resistivity zones that indicate the most likely locations of welded tuff where potential flow paths might be present. Figure $7 \mathrm{~b}$ shows the projection on this cross section of the known indicator data from nine adjacent wells. Again, the black areas represent the sections of the resistivity log that indicate densely-welded tuff. Due to their proximity, these wells have the greatest influence on the simulation along this cross section. Note that the influence of these known data depend on their distance away from the cross section. The influence of the known data diminishes as this distance approaches the range of horizontal correlation expressed in the indicator covariance model. The general character of the distribution of welded tuffs is reproduced as can be seen by comparing the distribution of simulated welded tuff to the location of the welded tuff and vitric tuff aquifers in the hydrogeologic cross section (shown in Figure 7c); that is, the welded tuffs tend to be indicated primarily in the upper half of the volcanic section.

Vertical cross sections through the subsurface data of Figure 6 showing equiprobable maps at $x=205,500,207,000$, and $208,800 \mathrm{~m}$ are presented in Figure 8 . Welded tuffs are found in both isolated locations and as parts of large connected zones. Connected zones of welded tuffs extending horizontally up to approximately $1 \mathrm{~km}$ are indicated. Note that although areas of connected welded tuff do not appear to extend across the entire domain, the horizontal extent in the $y$ direction, which is perpendicular to the page in this figure, may easily contribute to even larger spatial connectivity. In contrast, vertical connectivity of welded tuffs is usually no more than about $200 \mathrm{~m}$. This pattern, which is the consequence of the anisotropic covariance structure, illustrates the spatial anisotropy exhibited by volcanic tuff deposits (Istok et al., 1994).

It is important to recognize that the two-dimensional cross sections presented here cannot demonstrate the actual degree of three-dimensional connectivity of the welded tuff units because they cannot show the units beyond the plane of the cross section. To help visualize the three-dimensional connectivity, horizontal cross sections through the same equiprobable subsurface map at $z=780,800$, and $820 \mathrm{~m}$ are shown in Figure 9. To illustrate, the vertical cross section in Figure $7 \mathrm{a}$ indicates only discontinuous welded tuff between $y=260,000$ and $262,000 \mathrm{~m}$ at $z=800 \mathrm{~m}$. In contrast, the horizontal cross section (Figure 9) shows a region of nearly continuous welded tuff 


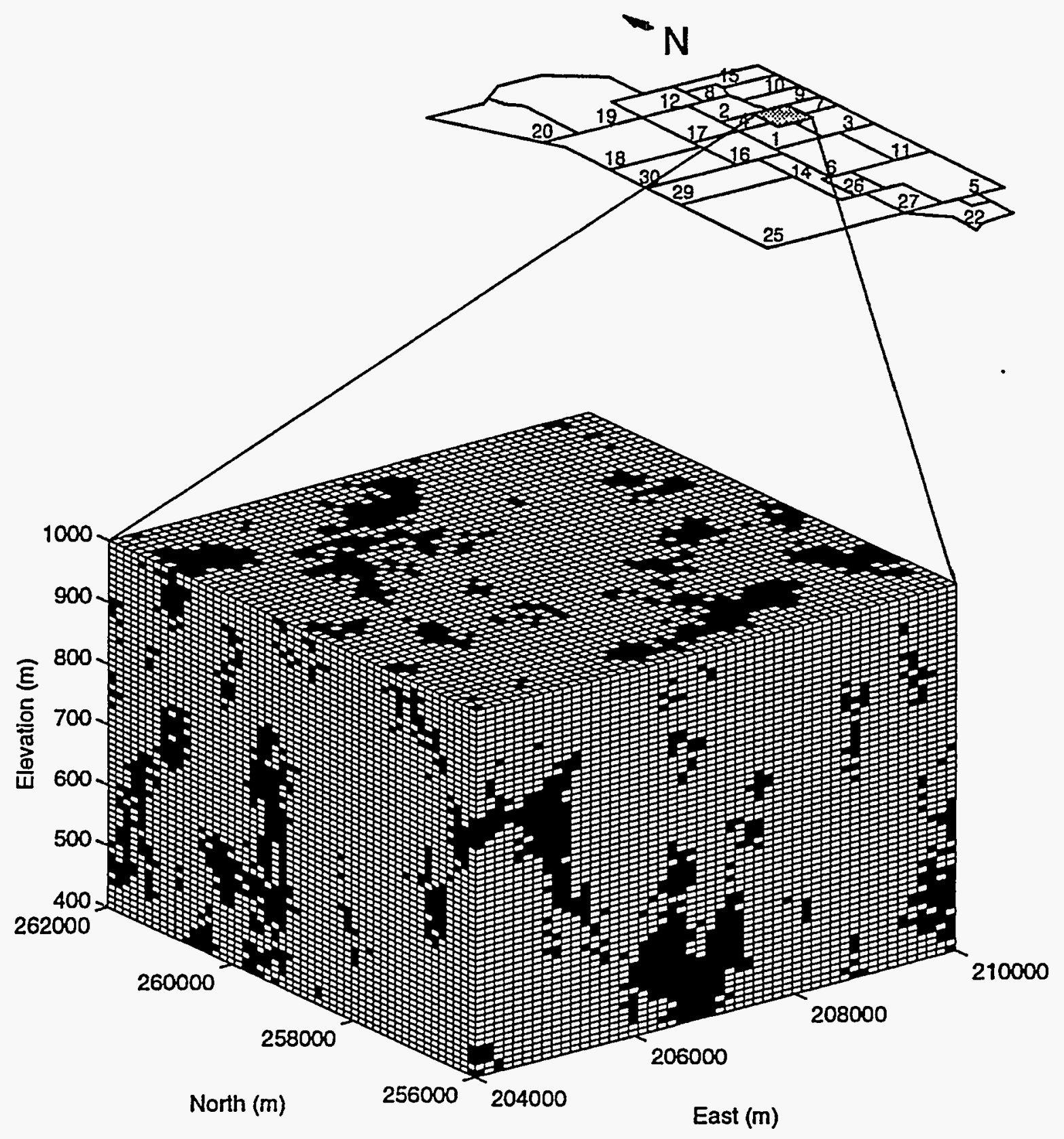

Figure 6. Three-dimensional perspective of the subsurface map of the volcanic section. The darker areas represent densely-welded tuff and the lighter areas represent nonwelded tuff. Note that the vertical axis is exaggerated by a factor of 7.5:1. 
(a)

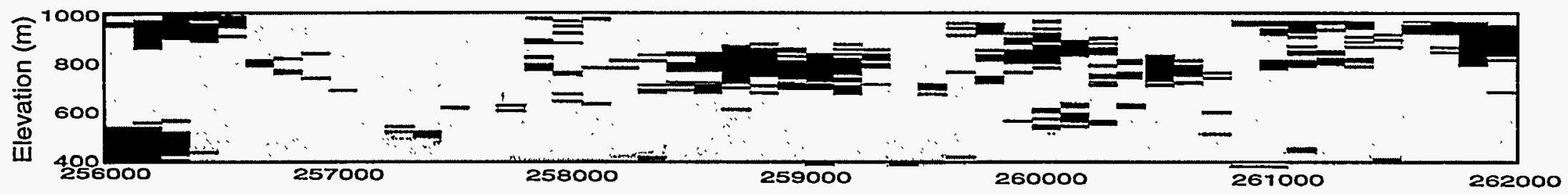

(b)

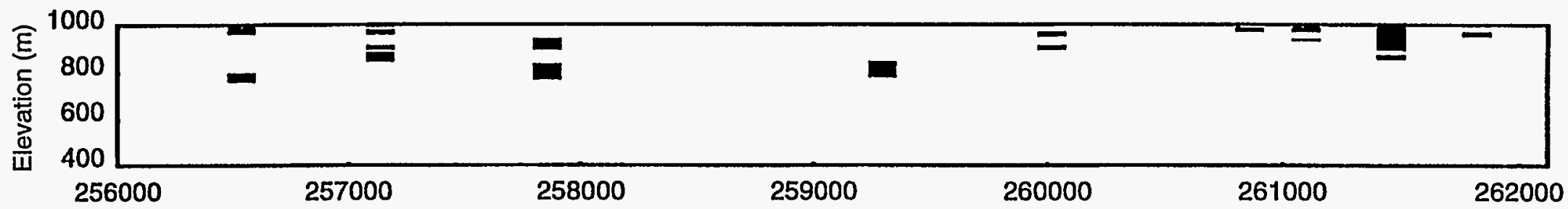

(c)

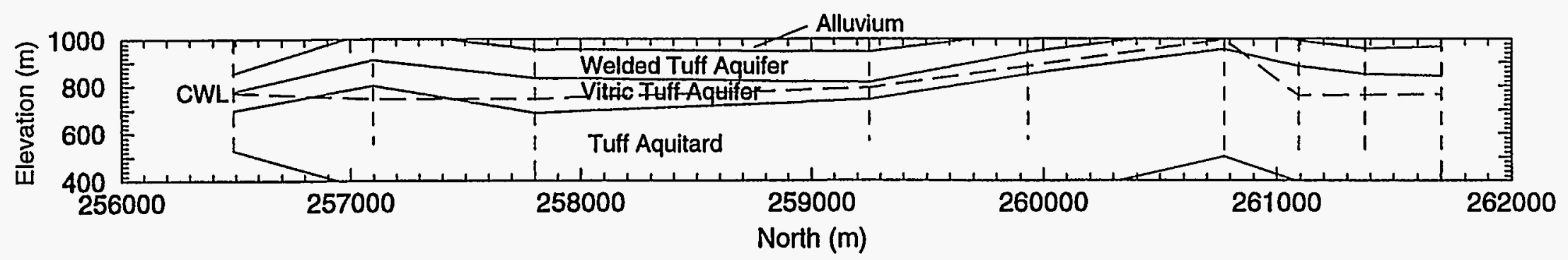

High Resistivity

[aw Resistivity

Figure 7. Comparison of (a) cross section through simulated subsurface map (b) known indicator data from nearby wells projected on section, and (c) hydrogeologic cross section. All cross sections are at $x=207,000 \mathrm{~m}$. The dark areas in (a) and (b) represent high resistivity zones that indicate densely-welded tuff. CWL is the composite water level measured in the boreholes. 
(a)

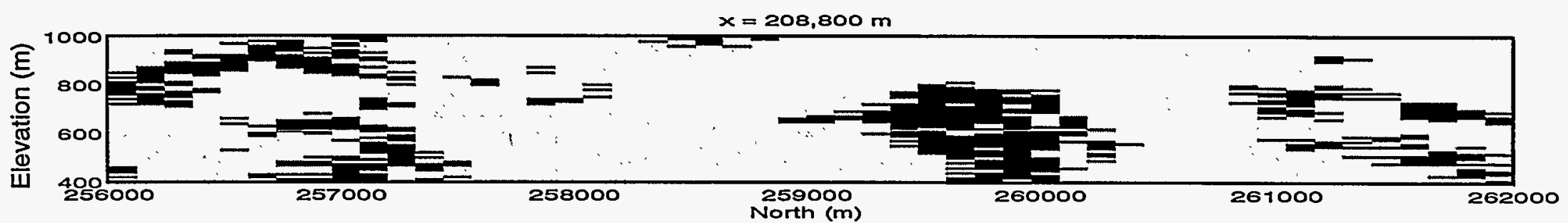

(b)

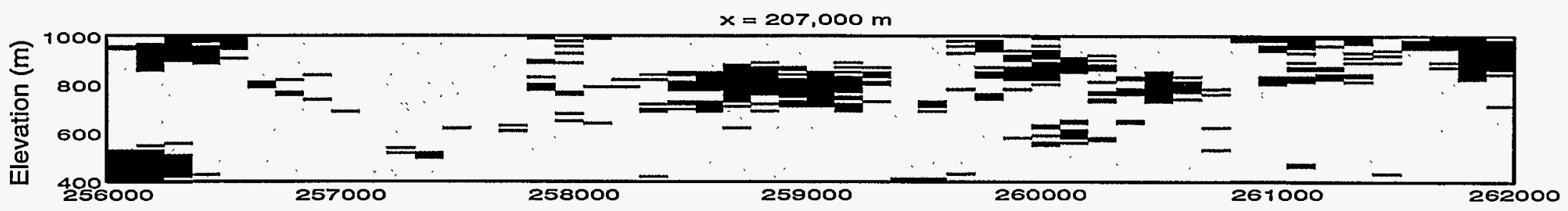

$\stackrel{\leftrightarrow}{\infty}$

(c)

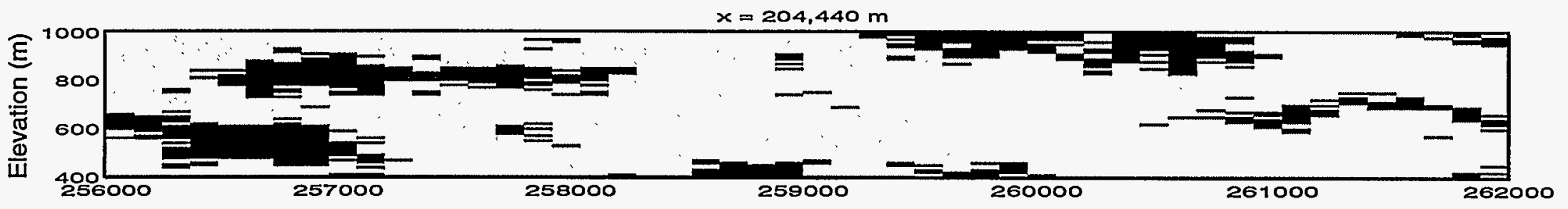

High Resistivity

$\square$ Low Resistivity

Figure 8. North-south cross sections through the simulated subsurface map at (a) $x=205,500 \mathrm{~m}$, (b) $x=207,000 \mathrm{~m}$, and (c) $x=208,800 \mathrm{~m}$. 

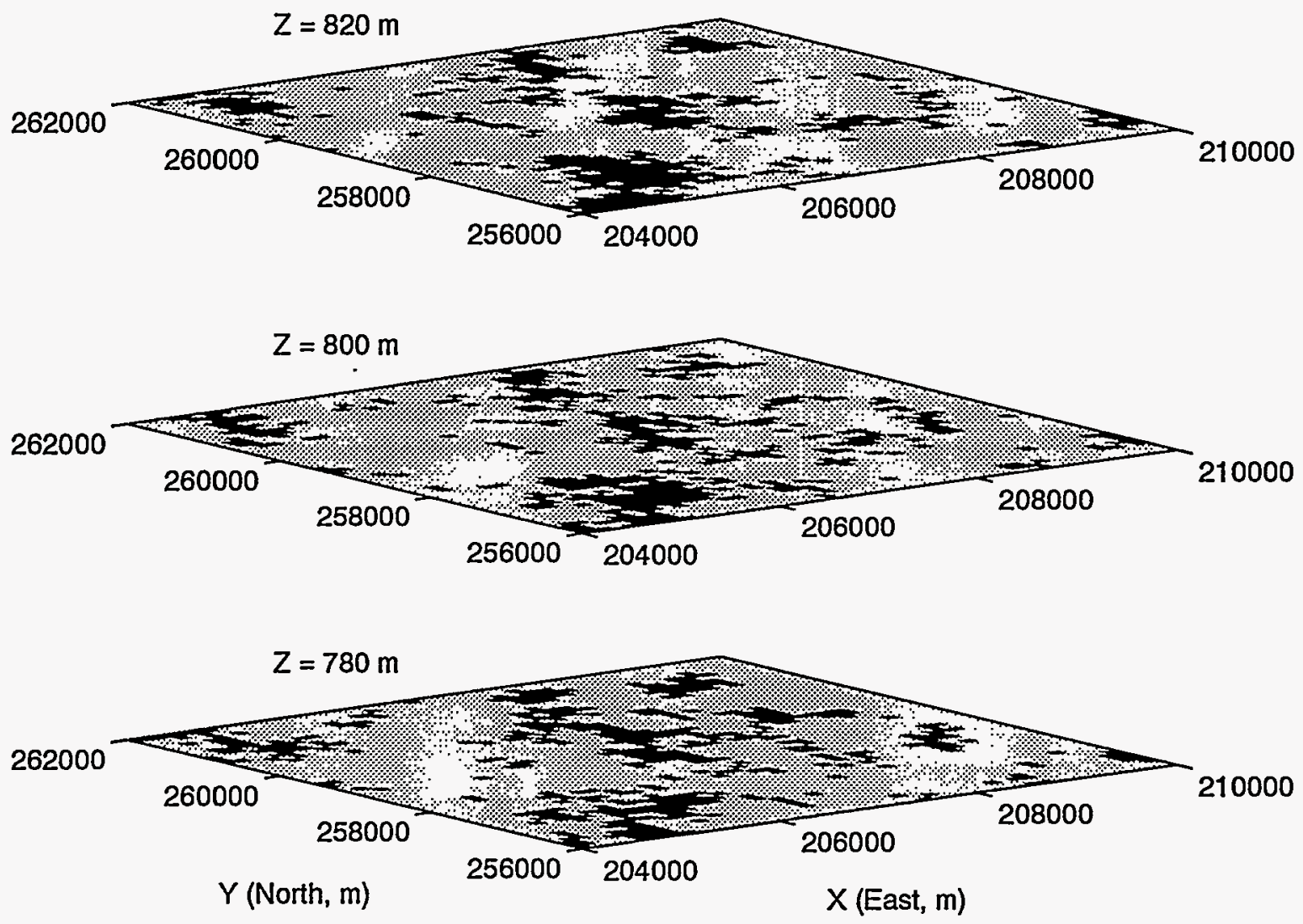

Figure 9. Horizontal cross sections through the simulated subsurface map at $z=780$, 800 , and $820 \mathrm{~m}$. Dark areas represent high resistivity zones that indicate densely-welded tuff. 
between $y=260,000$ and $262,000 \mathrm{~m}$ and $x=207,000$ and $208,000 \mathrm{~m}$. Furthermore, the section at $z=780 \mathrm{~m}$ indicates this zone of connected welded tuff extends south at least as far as $y=258,000 \mathrm{~m}$ at this elevation. Simultaneous evaluation of multiple vertical and horizontal cross sections within the volume data shows the increased connectivity that occurs when three dimensions are simulated in the study. Clearly, the connectivity patterns must be simulated and evaluated as three-dimensional volume data as they exist in real subsurface hydrostratigraphic units.

In this first phase of the project, the problem domain was oriented in Cartesian coordinates. This coordinate system does not preserve variations in stratigraphic depth or thickness, if they occur. An implication of this may be that the horizontal indicator semivariogram search may extend beyond the boundaries of a particular hydrostratigraphic unit that dips or exhibits variable thickness. As a result, the distance at which correlation no longer exists may be artificially slightly reduced and may be transferred to the simulation through an artificially smaller correlation range. The conmectivity of welded tuffs demonstrated in the simulations presented here may therefore be slightly underestimated.

Figure 10 shows the three realizations of the subsurface map as cross section at $x=207,000$. All three realizations were simulated using identical known conditioning data and spatial correlation structure, and therefore all three are equally probable representations of the distribution of welded tuff. The differences between these realizations result from the prevailing spatial uncertainty, particularly when a small amount of conditioning data are found in the search neighborhood. When no conditioning data are found, ISIM3D chooses an indicator from a bivariate distribution based on the cpdf.

\section{CONCLUSIONS AND RECOMMENDATIONS}

Several three-dimensional realizations of the distribution of densely-welded and nonwelded tuffs in the volcanic section below a portion of Yucca Flat were generated to demonstrate the SIS methodology. Resistivity was used as the hydrogeologic attribute to indicate the presence of welded tuff verses nonwelded tuff. Welded tuffs may act as groundwater flow paths within the volcanic section at Yucca Flat.

The simulations demonstrate that resistivity log data works well as an indicator of densely-welded tuffs. The simulated welded tuffs reproduce the stratigraphic relationships of the welded tuff and vitric tuff aquifers as represented by hydrogeologic cross sections, while incorporating the heterogeneity and anisotropicity that would be expected from these units in a subsurface setting.

Results of the simulations suggest that connected zones of welded tuff exist within the volcanic section at Yucca Flat. Two-dimensional cross sections show areas of connected welded tuff up to one $\mathrm{km}$ in length and $200 \mathrm{~m}$ in height. Three-dimensional, as opposed to two-dimensional, simulations increase the chance for connectivity of welded units, and groundwater flow paths. As a result, zones of connected welded tuffs indicated on the two-dimensional figures presented here may actually extend beyond the limits mentioned above. 
(a)

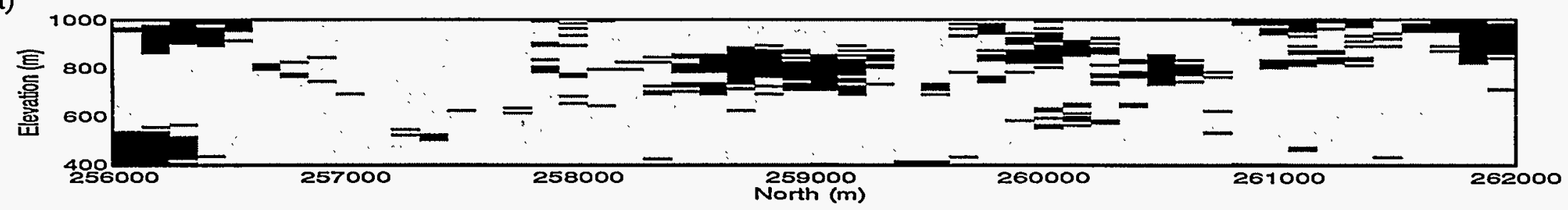

(b)

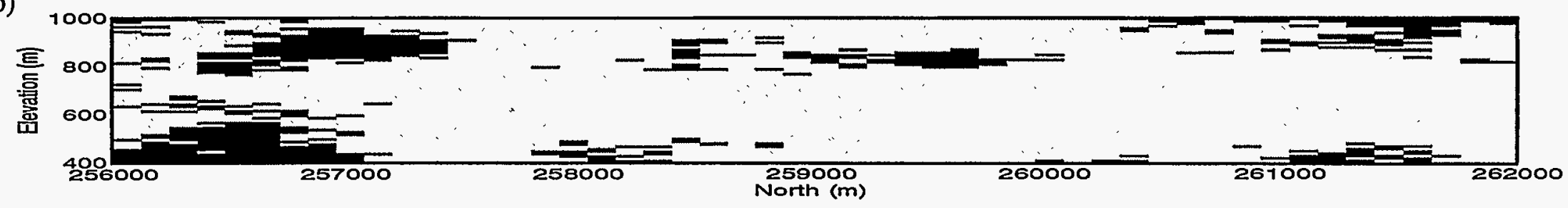

(c)

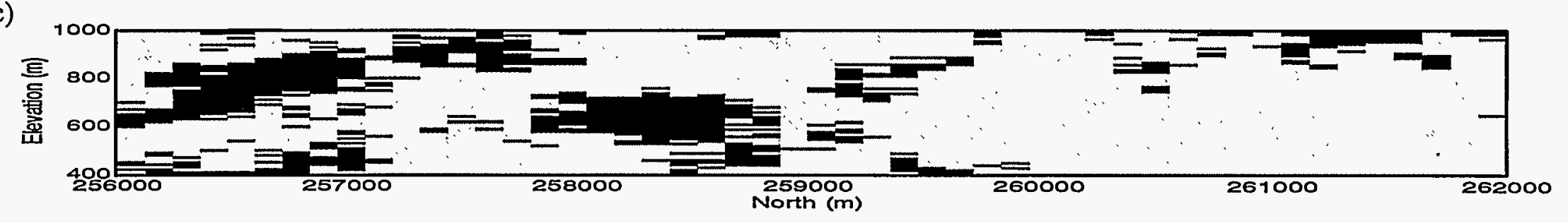

High Resistivity

$\square$ Low Resistivity

Figure 10. Comparison of three realizations of the subsurface map at $207,000 \mathrm{~m}$ East. Note that although they differ slightly in the distribution of the densely-welded and non-welded units, all three realizations are equally probable. 
From this point, the project should continue to establish and apply the methodology for generating equiprobable maps of hydraulic conductivity. To improve the maps of the distribution of important hydrostratigraphic units produced in this first phase of the effort, other geophysical logs (e.g., gamma-gamma and neutron) should be utilized. When all sources of available soft data have been exhausted, the generated maps should be calibrated to available hard data and this new information considered as soft data. These soft data maps can then be used to augment the available hard data to generate maps of hydraulic conductivity. The maps of hydraulic conductivity will be evaluated using the transformed coordinates accounting for variations in stratigraphic depth or thickness. The final maps of hydraulic conductivity will then be available for use as input to numerical models of groundwater flow and transport.

\section{REFERENCES}

Alabert, A., 1987. Stochastic imaging of spatial distributions using hard and soft information. M.S. Thesis, Appl. Earth Sci. Dept., Stanford Univ., 184 pp.

Blankennagel, R.K. and J.E. Weir Jr. 1973. Geohydrology of the Eastern Part of Pahute Mesa, Nevada Test Site, Nye County, Nevada. U.S. Geological Survey Professional Paper 712-B, 35 pp.

Dagan, G., 1986. Statistical theory of groundwater flow and transport pore to laboratory, laboratory to formation, and formation to regional scale. Water Resour Res., 22(9), 120S-135S.

Delhomme, J.P., 1979. Spatial variability and uncertainty in groundwater flow parameters: A geostatistical approach. Water Resour. Res., 15(2), 269-280.

Deutsh, C.V. and A.G. Journel, 1992. GSLIB: Geostatistical Software Library and User's Guide. Oxford Univ. Press, 340 pp.

Drellack, S.L. Jr., 1994. An Introduction to NTS Geology and Geophysical Log Characteristics.

- Raytheon Services Nevada, 68 pp.

Drellack, S.L. and P.H. Thompson, 1990. Selected Stratigraphic Data for Drill Holes in LANL Use Areas of Yucca Flat, NTS. Fenix \& Scisson of Nevada Geologic Report, DOE/NV/10322-39, $188 \mathrm{pp}$.

Gelhar, L.W., 1986 Stochastic subsurface hydrology from theory to applications. Water Resour. Res. 22(9) 1355-1455.

Gomez-Hernandez, J.J. and R.M. Srivastava, 1990. ISIM3D: An ANSI-C three-dimensional multiple indicator conditional simulation program. Comp. \& Geo S., 16(4), 395-440.

Istok, J.D., C.A. Rautman, L.E. Flint and A.L. Flint, 1994. Spatial variability in hydrologic properties of a volcanic tuff. Ground Water, 32(5), 751-760.

Journel, A.G., 1989. Fundamentals of geostatistics in five lessons. Short course in Geology: Vol. 8, American Geophysical Union, 40 pp. 
Journel, A.G. and F.G. Alabert, 1990. Non-Gaussian data expansion in the Earth sciences. Terra Nova, 1(2), 123-134.

Keys, W.S., 1990. Borehole Geophysics Applied to Groundwater Investigations. TWRI-2-E2, U.S. Geol. Survey, 150 pp.

Winograd, I.J., and W. Thordarson, 1975. Hydrogeologic and Hydrochemical Framework, South-Central Great Basin, Nevada-California, with Special Reference to the Nevada Test Site. U.S. Geol. Survey Professional Paper 712-C, 126 pp. 


\section{DISTRIBUTION}

\section{U.S. Department of Energy}

Gylan Allen

Test Operations Division

Nevada Operations Office

U.S. Dept. of Energy

P.O. Box 98518

Las Vegas, NV 89193-8518

Doug Duncan

Hydrology Program Manager

Office of Environmental Restoration \& Waste

Management

Nevada Operations Office

U.S. Dept. of Energy

P.O. Box 98518

Las Vegas, NV 89193-8518

Don Elle, Director

Environment Protection Division

Nevada Operations Office

U.S. Dept. of Energy

P.O. Box 98518

Las Vegas, NV 89193-8518

Joseph N. Fiore, Acting Asst. Mgr.

Office of Environmental Restoration \& Waste Management

Nevada Operations Office

U.S. Dept. of Energy

P.O. Box 98518

Las Vegas, NV 89193-8518

Joseph H. Kitchen

Technology and Program Management Division

Nevada Operations Office

U.S. Dept. of Energy

P.O. Box 98518

Las Vegas, NV 89193-8518

Steve Lawrence

Environmental Restoration Division

Nevada Operations Office

U.S. Dept. of Energy

P.O. Box 98518

Las Vegas, NV 89193-8518
John S. Ledbetter

Contracts Division

Nevada Operations Office

U.S. Dept. of Energy

P.O. Box 98518, MS 505

Las Vegas, NV 89193-8518

Steve Leedom

Test Operations Division

Nevada Operations Office

U.S. Dept. of Energy

P.O. Box 98518

Las Vegas, NV 89193-8518

Steve Mellington, Director

Environmental Restoration Division

Nevada Operations Office

U.S. Dept. of Energy

P.O. Box 98518

Las Vegas, NV 89193-8518

Richard Pearl

Environmental Restoration Division

Nevada Operations Office

U.S. Dept. of Energy

P.O. Box 98518

Las Vegas, NV 89193-8518

\section{U.S. Department of Defense}

David Bedsun

Defense Nuclear Agency

U.S. Department of Defense

P.O. Box 98539

Las Vegas, NV 89193-8539

Lawrence Livermore National Laboratory

Lee Davisson

Nuclear Chemistry Division

Lawrence Livermore National Laboratory

P.O. Box 808, MS L237

Livermore, CA 94550

Greg Nimz

Lawrence Livermore National Laboratory

P.O. Box 808, MS L233

Livermore, CA 94550 


\section{Los Alamos National Laboratory}

Joe Thompson

Los Alamos National Laboratory

INC-11, MS J514

P.O. Box 1663

Los Alamos, NM 87545

\section{U.S. Geological Survey}

Virginia Glanzman

U.S. Geological Survey

Box 2506, MS 913

Denver Federal Center

Denver, CO 80225

Randy Laczniak

U.S. Geological Survey

Water Resources Division

6770 S. Paradise Rd.

Las Vegas, NV 89119

Paul Orkild

U.S. Geological Survey

Box 2506, MS 913

Denver Federal Center

Denver, CO 80225

Doug Trudeau

U.S. Geological Survey

Water Resources Division

6770 S. Paradise Rd.

Las Vegas, NV 89119

\section{Desert Research Institute}

Roger Jacobson

Desert Research Institute

Water Resources Center

P.O. Box 19040

Las Vegas, NV 89132-0040

Marjory Jones

Desert Research Institute

Water Resources Center

P.O. Box 60220

Reno, NV 89506-0220
Dick French

Desert Research Institute

Water Resources Center

P.O. Box 19040

Las Vegas, NV. 89132-0040

Reynolds Electrical \& Engineering Co.

Martha DeMarre

Chief, Document Research Section

Health Protection Dept.

Reynolds Electrical \& Engineering Co.

P.O. Box 98521

Las Vegas, NV 89193-8521

Brian Dozier

Reynolds Electrical \& Engineering Co.

2501 Wyandotte

Mercury, NV 89102

State of Nevada

Larry Franks

Nevada State Health Department

Radiological Health Section

620 Belrose Avenue

Las Vegas, NV 89158

\section{Libraries}

Annie Kelley

State Documents Department

Nevada State Library

Capitol Complex

Carson City, NV 89710

Archives

Getchell Library

University of Nevada, Reno

Beverly Carter

MacKay School of Mines Library

University of Nevada, Reno

Document Section, Library

University of Nevada, Las Vegas

4505 Maryland Parkway

Las Vegas, NV 89154

Southern Nevada Science Center

Water Resources Center, Library

P.O. Box 19040

Las Vegas, NV 89132-0040 
Stead Library

Desert Research Institute

Reno, Nevada

Technical Information Resource Center

Nevada Operations Office

U.S. Dept. of Energy

P.O. Box 98518

Las Vegas, NV 89193-8518

Water Resources Research Archives

University of California

Room 40, North Gate Hall

Berkeley, CA 94720
International Technology Corp.

Rick Waddell

Geotrans

c/o IT

4330 Valley View

Suite 112

MS-439

Las Vegas, NV 89103

Joe Yeasted

International Technology Corp.

4330 S. Valley View

Suite 114

Las Vegas, NV 89132-0040 